logos_i_ethos_2019_special_issue, pp.59-87

DOI: http://dx.doi.org/10.15633/lie.3469

Bożena Listkowska

ORCID: https://orcid.org/0000-0002-6635-5934

\title{
Gogacz - Judycki. Two concepts of the individuality of a human person
}

In the research paper Samoświadomość i unikalność osób ludzkich Stanisław Judycki points out the disparity in the discussion of the individuality of human persons. Over the history of philosophy the individuality of persons against the backdrop of the natural world has

Bożena Listkowska (Casimir the Great University in Bydgoszcz) - a doctor of philosophy; an assistant professor at the Institute of Philosophy, Casimir the Great University in Bydgoszcz. Scope of research interests: contemporary Polish philosophy, in particular philosophical anthropology and metaphysics.

frequently been an object of study, but attempts at answering the question of what is a person's individuality in the world of other human persons have been few and far between. The call "Gnothi seauton" (know thyself) inscribed in stone at the ancient temple in Delphi seems to imply that the question of individuality has been present in philosophical reflection since antiquity. But that is not the case. The true intention behind the above-mentioned inscription was not to urge man to know himself as a unique individuum, but to make him realise mortality and imperfection, in contrast to God's immortality and perfection. Nor does the Boethian definition of person convey the sense of individuality we wish to address here. In the statement "Persona est rationalis naturae individua substantia" (a person is an individual substance of rational nature) the term individua is used to signify particularity as opposed to generality, that is a universal, and not uniqueness. The question of a person's individuality understood as his uniqueness appeared in the medieval scholastic philosophy, but it was not a separate philosophical problem. More often than not, it was addressed as part of 
theological deliberation. Nowadays, it is theology and psychology rather than philosophy that discuss the uniqueness of a person. ${ }^{1}$

The proposition whereby each human person is an individual being essentially different than any other human persons will be illustrated with the concepts of individuality developed in the contemporary Polish philosophy by Mieczysław Gogacz and Stanisław Judycki. The following discussion will serve as a look at the problem of individuality taken from two different philosophical perspectives: Thomistic metaphysics and phenomenological epistemology. The answer to the question about the individuality of a human person is of particular relevance for Thomism and phenomenology, in which the issues concerned with man as a person constitute one of the central points in philosophical inquiry. The purpose of the present discussion is to demonstrate that the metaphysical analysis of a human person and the epistemological description of his direct experience are peculiarly complementary approaches. The Thomistic reflection seeks to answer the question about who man is as an individual being, while phenomenological reflection seeks to answer the question of how man experiences himself as an individuum. These approaches contribute irreducible and yet crucial contents to the philosophical knowledge of man.

\section{Defining individuality}

Mieczysław Gogacz attempts to find the basis of the individuality of a human person in his ontic structure. He addresses the problem of individuality while discussing the relationship between man's soul and body. ${ }^{2}$ The method he employs as he develops his propositions is one of

1 Cf. S. Judycki, Samoświadomość i unikalność osób ludzkich, http://www.kul.pl/materialy-do-pobrania,art_19301.html, PDF: p. 7 (02.04.2014) and cf. A. Kijewska, Filozof i jego muzy. Antropologia Boecjusza - jej źródła i recepcja, Kęty 2011, p. 108.

2 "The European intellectual culture first witnessed the rise of the issues concerned with man. [...] The issues concerned with the person were developed along with Christianity. This is because the understanding of man was complicated by the figure of Christ, who according to the Christian Revelation is both God and man. In order to shed more light on this intractable ontic structure [...], 
identification of the principles of being. He proves his propositions by referring to the method of consistentisation, that is demonstrating that accepting an opposite thesis will result in absurdity.

Stanisław Judycki looks for the foundation of individuality in analysis of direct experience. He inquires about the reason for the presence in human consciousness of "I," that is the subject of conscious processes. As he proves his propositions, he refers to the consistency of theses developed on a discursive basis or employs content coherence arguments. He makes use of descriptions and analogies which perform an illustrative function in his discussion. ${ }^{3}$

\subsection{Thomistic definition of individuality}

To define individuality, Gogacz uses the terms "individual," "unique" and "singular." He uses them in reference to every real being - every existing concretum. He distinguishes real beings from thought "beings," that is constructs of the intellect, artefacts of technology and art. In the field of metaphysics he focuses his attention on real beings only. $\mathrm{He}$ excludes thought "beings" and artefacts from the sphere of metaphysical deliberation. Every real being, he claims, is formed out of the act of existence, which is a reason for its reality, and out of the essence constituting the reason for its identity. The Absolute, an ontically simple being formed out of the act of existence, is an exception. As the Selfcontained Act of Existence, that is an uncaused being, it is an efficient cause of all accidental beings. The Self-contained Act of Existence does not create beings, but acts of existence. This does not mean that the existence of a created being is apart from its essence. In the order of time creating existence takes place simultaneously with the rise of being as a whole. Simultaneous with the action of the efficient cause, which creates the existence of derivative being, is the action of the final causes,

the issues concerned with the person were addressed" (M. Gogacz, Wokót problemu osoby, Warszawa 1974, pp. 14-15).

3 Cf. S. Judycki, Bóg i inne osoby. Próba z zakresu teologii filozoficznej, Poznań 2010, pp. 11-12. 
which are the reasons for its essence. As regards man, parents are the causes of body, and spiritual substances (separate substances) are causes of his soul. A created act of existence acts in the emergent being, making it real and actual. Making real consists in originating, realising of being, and making actual consists in connecting all the principles with the act of existence, thereby causing ontic unity. ${ }^{4}$

In the order of being, existence is an act, and essence is potency. In relation to the act of existence, essence is a sum of specific particularisations peculiar to a given act of existence. As it actualises the essence of being, the act of existence actualises in it a species-specific form, that is a soul. A form, which is an act in the order of essence, imparts essential definiteness to the sphere of potency. If the act of existence did not actualise in the essence of being its form, beings would be devoid of species identity and thus would be identical. They would lack principium underlying being a plant, an animal or a human. The essential sphere of potency, actualised by form, includes material potency and immaterial potency. Material potency along with material accidents constitutes a human body. In the Thomistic tradition it is customarily assumed that the singularity of man, and his distinctness from all other individua in the same species is determined by matter. And on account of this - asks Gogacz - at the moment of death, which marks separation of matter and form, does the human soul lose its individuality? Is the destruction of man's ontic structure tantamount to the destruction of his personal duration? That is the main metaphysical problem to be confronted on the threshold of the theory of the individuality of a human person. ${ }^{5}$

\subsection{Phenomenological definition of individuality}

Every living entity is individual. The individuality of nonpersonal entities is different from the individuality of persons. The

${ }^{4}$ Cf. M. Gogacz, Elementarz metafizyki, Warszawa 1998, p. 32.

5 Cf. ibidem, p. 31 and I. Ziemiński, Życie wieczne. Przyczynek do eschatologii filozoficznej, Kraków-Poznań 2013. 
latter is something far more perfect, a radical otherness of "worlds," a "metaphysical uniqueness." Non-personal entities can only be referred to as "individual," while personal entities as "unique." Inanimate objects and non-personal entities are individuated by space, time and bestowed properties. As regards persons, space and time are "weak" individuators. They can be considered to be signs of individuality (indicia individuationis), but not principles of individuality (principia individuationis). Space and time individuate persons only formally. The same goes for bestowed properties - these individuate inanimate objects to a greater degree than persons. This is because even highly complicated "constellations of properties," that is arrangements of both physical and non-physical characteristics are replicable, but also because the uniqueness of persons is not a superstructure over their properties. An example of such a superstructure may be a melody which appears over the substructure of a sequence of sounds, thus creating a new quality. If persons were individuated by arrangements of properties, the same persons might be created many times. ${ }^{7}$

The only factor appropriately individuating persons can be a quality not built on top of any ensemble of properties, that is an absolutely simple quality. Human persons - claims Judycki - are different in that each one of them is a "unique quality." A unique quality of a person is not a "constellation of properties," but unique content. Consequently, getting to know a person differs fundamentally from getting to know his character traits. The knowledge of character traits is not knowledge of a person himself, or his "individual nature." 8 Getting to know a person

6 "[...] I would like to reserve the term «uniqueness» for personal beings, that is free, rational and self-conscious beings, while leaving the term «individuality» to be used in reference to all other beings. I will be trying to demonstrate that only persons are unique beings" (S. Judycki, Samoświadomość i unikalność..., p. 8).

7 Cf. ibidem, pp. 9-10.

8 " [...] the subject that I am does not identify with any of its character traits, nor with any one of the objects that it is aware of, and on account of this one might want to follow Edmund Husserl, one of the famous philosophers of the 20th century, in saying that this subject is a «pure I and nothing more». However, if it were the case, if my consciousness and my self-discovery were based on the pure subject, that is the subject with no properties, then the questions of who we are and who 
would be possible only if it were possible to identify his singularity. Does the general and notional character of human cognition allow that? How can we establish that that which we have recognised as uniqueness is in fact uniqueness? How can we identify uniqueness and differentiate it from that which is not unique? Such are the greatest difficulties emerging at the starting point for epistemological deliberations. ${ }^{9}$

As can be seen, Thomism and phenomenology differently define the individuality of a person and are confronted by different difficulties. When treated separately, the Thomistic and phenomenological approaches constitute fragmentary knowledge of the individuality of a person. These two fragments are two different perspectives from which to view the individuality of a human person. Thomism places philosophical reflection in the outer, objective perspective, whereas phenomenology in the inner, subjective one.

\section{The subject of individuality}

\subsection{Man as an individuum}

Highlighting the individuality of man within Thomistic metaphysics is about pointing to the essential dissimilarity between his ontic structure and the ontic structure of other beings accessible to sensuous and intellectual cognition, that is plants and animals. The structure of man can be discovered by way of analysing his actions. The first kind of actions is getting to know the world and reacting to the world in a sensory manner. Man can see and hear, can sense olfactory, gustatory and tactile stimuli, as well as nourish feelings and desires. These actions indicate presence of sensory powers of cognition and aspiration in his essence. We can observe effects of their activity in the body. Therefore, we can

we consider ourselves to be would be even more pressing. In a case like this someone might want to return to the starting point and say: "After all we are humans, corporeal beings endowed with reason, capable of culture creation and of action». That, however, would not appear to be a good answer, because it would not be clear who as an individuum this rational, corporeal being capable of producing cultural goods, etc. is" (ibidem, p. 7).

9 Cf. ibidem, p. 6. 
assume that an element of the essence of man is material potency along with material accidents subjectified in this essence, but not intrinsic to it due to being ontically unnecessary.

Another kind of human actions consists in developing concepts, passing judgements, engaging in reasoning and making decisions. Because these actions and their effects are immaterial, we agree that their subject is immaterial as well. It is immaterial potency thanks to which man has a power of cognition, that is intellect, and a power of aspiration, that is will. Material and immaterial potency requires that the existence of an act-like factor triggering the two types of potency be accepted as existing within the essence of man. It is a substantial form, that is a human soul. ${ }^{10}$

Man is a spiritual and corporeal unity. ${ }^{11}$ Neither his soul, nor his body is a substance. A body is a substance in no sense whatsoever. Nor is it actuality, that is an act, nor can it exist independently. It is potentiality, an ensemble of unactualisations, a sum of particularisations inside a form, a factor imparting ontic imperfection to a soul. ${ }^{12}$ A soul is a complete substance with regard to existence, but an incomplete substance with regard to a species. It does not exist before emergence of being as an entirety. As a form of a body, it cannot exist without matter that brings particularity into it. When it comes into being, it can last even when separated from the body. As it rids the soul of material potency, death

10 Cf. M. Gogacz, Istnieć i poznawać, Warszawa 1978, pp. 160-161.

11 "When the body pervades the soul, it is a particular being from the start. And on account of this one might even make quite a paradoxical statement that there is no soul as a soul, but from the very moment the act of existence realises this form which is made imperfect by potency, there is man, just man. It is only actions specific to man that indicate his spiritual and material structure, a peculiar compound thanks to which man is not an absolute act in the order of essence, nor a pure being in the order of real being. Such an approach is pluralistic" (ibidem, p. 168).

12 "If we call this visible structure with a specific shape, colour, dimensions a human body, then it means that we have introduced into the area of philosophy a positivist notion of matter, equated with being of a complex and complete - specific to a given being - structure without which it is impossible to exist as something specific, as this particular being. According to the classical philosophy the human body cannot be a substantial being, nor can it be an act. It must be potency. [...] Only something that is still being actualized, that is not yet accomplished, that is still becoming in man can be a body" (ibidem, p. 161). 
"cripples" it, preventing it from continuing in ontic unity with the body, but it does not destroy it. The human soul is a spiritual act, which as such is not subject to destruction, unlike immaterial forms of plants and animals which cease to exist once their corporeal structures are destroyed. ${ }^{13}$

The substantial forms of animals and plants are not spiritual, but only immaterial and because of this are less firmly coupled with the act of existence than the rational form. Gogacz attributes a special ontic role to rationality. He claims that the rational soul requires "[...] such a structure distinct from other forms, where immateriality is complemented by the soul's stronger link with existence than with potency. Apart from the human soul, the forms of beings in a sense lean in the direction of their specific potency, rather than in the direction of existence. And when separated from the act of existence, they share the fate of matter, that is they perish, because matter, as peculiar non-being perishes when it is not embedded in some subject. A soul leaning more towards existence in the event that man ceases to exist - does not become separated from existence but from potency, that is the body." ${ }^{14}$

The human soul lasts after man's death, because its goal is not accomplished in forming the body - actualising matter. It is capable of rational cognition thanks to spiritual powers of cognition, which are the passive intellect (intellectus possibilis) and the active intellect (intellectus agens). It is also capable of accepting the results of its cognition thanks to the spiritual power of choice, that is will (voluntas). As it possesses spiritual powers of cognition and decision, it has a "richer ontic structure" than the souls of animals and plants. It has its own internal life, which is different than the one the body brings to it. As the body penetrates the soul, it makes it imperfect, but it does not rid it of autonomy; on the contrary, it conditions the autonomy. It is a source originating the soul's cognitive activities. The autonomy of the soul's activity determines its continuation after being separated from the body. ${ }^{15}$

13 Cf. ibidem, pp. 162-163.

14 Ibidem, pp. 163-164.

15 Cf. ibidem, p. 165. 
Gogacz's philosophy of being is a metaphysics of an individual being. The author calls it ontic pluralism. Underlying it is the thesis about the uniqueness of the principles of being, which he uses to construct a thesis about the uniqueness of every individuum having real existence. In his works he emphasises the complete interpenetration of the soul and the body, their ontic unity. He assumes that the human soul possesses a radically different nature than the nature of the body, but at the same time he categorically dissociates himself from dualism. He terms it like monism - a metaphysical error. Therefore, he finds anthropological concepts by, inter alia, Plato, Descartes ${ }^{16}$ to be erroneous, but even in Saint Thomas he can discern traces of the dualist perception of man. He claims that Thomas Aquinas does not always emphasise the complete interpenetration of the body and soul strongly enough. He notes that philosophers readily refer to dualism, where the body is perceived as functional, as a tool used by the soul during its earthly life, because in the dualist scheme of things it is easier to substantiate the existence of the soul after it is separated from the body. ${ }^{17}$ The theory of the complete interpenetration of body and soul involves the necessity to provide the reason for the autonomous existence of the soul after a man's death. As they try to overcome this difficulty, Thomists resort to a solution consisting in weaker highlighting of the interpenetration of body and

16 "Dualism consists in the parallel being of purely spiritual structures and purely material structures. That is the form it takes - as we know - in Plato, but first and foremost in Descartes. And this Platonic or Cartesian concept of dualism is the tool most frequently utilised when explaining the relationship between the body and soul. The soul is then treated as a non-complex structure, as is the body. Autonomous being, bound parallel to the soul, is attributed to the body. This parallelist dualism is easy to identify and refute, demonstrating the contradiction of pure, internally non-complex beings besides God" (ibidem, p. 167).

17 "In pure dualism this matter [demonstrating existence of the soul after it has been attached to the body - B. L.] does not pose a problem. The soul is a structurally simple being and becomes attached to the body, which is a non-complex substance as well, in a practically seeming and completely external manner. As the soul becomes detached from the body, it acquires its specific mode of being, not embroiled in an ontically vague connection with the body. Plato was right in explaining this vague connection by resorting to an additional theory of punishment" (ibidem, p. 169). 


\section{soul, as well as to the theory of commensuratio. ${ }^{18}$ Gogacz flatly rejects the first element of this solution, while he reinterprets the second one. ${ }^{19}$}

\subsection{The subject of consciousness as an individuum}

\section{The operation of human consciousness naturally directs man towards reflection on himself as an individual entity, making him ask the question:}

18 The Thomistic tradition gave rise to the theory of commensuratio animae ed hoc corpus as a development of Saint Thomas Aquinas' idea of the soul's adjustment to a specific body. As it exists in the body, the human soul gets individuated by matter. Death constitutes a rift in man's natural structure, a separation of matter and form, body and soul. To demonstrate the entity's immortality Saint Thomas contended that the human soul is oriented towards the body, with which during man's lifetime it constitutes an ontic whole. The idea not only served to defend the entity's immortality, but also expressed the belief that transmigration of souls, i.e. reincarnation, is not possible. Saint Thomas understood a soul's orientation towards a specific body as a consequence of the proportion of the soul to the body, of their mutual adjustment. He did not explicite use the formula commensuratio animae ad hoc corpus, but the term commensuratio (adaptation, symmetry, commensurateness), which he used alongside such terms as habitudo (habituation, conditioning) and proportio (proportion). The expression commensuratio animae ad hoc corpus was and still is used by the continuators of Aquinas' ideas, inter alia, Kajetan, S. Swieżawski, M. Krasnodębski et al. The idea of the soul's adaptation to a specific body features in many of Aquinas' texts, e.g. De ente et essentia (cap. 2), De Veritate (q. 2 a. of. 9-10, a. 5), Scriptum super "Sententias" (Lib. IV, d. 12, q. 1, a. 1, ad 3), Expositio super librum Boethi "De Trinitate" (q. 4, a. 2), Summa contra gentiles (Lib. I, cap. 21; Lib. II, cap. 81; Lib. IV, cap. 63) and Summa theologiae (I, q. 29, a. 3, ad 4; I, q. 75, a. 5; I, q. 85, a. 1; I, q. 86, a. 3 et al.). Cf. M. A. Krąpiec, Zagadnienie jednostkowienia bytów materialnych, "Roczniki Filozoficzne" 1958, vol. 6 bull. 1, pp. 106108. In his Summa contra gentiles Thomas Aquinas expresses the idea of commensuratio, inter alia, in the following words: "Multitudo igitur animarum a corporibus separatarum consequitur quidem diversitatem formarum secundum substantiam, quia alia est substantia huius animae et illius: non tamen ista diversitas procedit ex diversitate principiorum essentialium ipsius animae, nec est secundum diversam rationem animae; sed est secundum diversam commensurationem animarum ad corpora; haec enim anima est commensurata huic corpori et non illi, illa autem alii, et sic de omnibus. Huiusmodi autem commensurationes remanent in animabus etiam pereuntibus corporibus: sicut et ipsae earum substantiae manent, quasi a corporibus secundum esse non dependentes. Sunt enim animae secundum substantias suas formae corporum: alias accidentaliter corpori unirentur, et sic ex anima et corpore non fieret unum per se, sed unum per accidens. Inquantum autem formae sunt, oportet eas esse corporibus commensuratas. Unde patet quod ipsae diversae commensurationes manent in animabus separatis: et per consequens pluralitas" (Thomas Aquinas, Contra Gentiles. On the truth of the catholic faith, Book Two: Creation, translated by James F. Anderson, New York 1955-57, http://dhspriory.org/thomas/ContraGentiles2.htm\#81 [accessed 02.04.2014]).

19 Cf. M. Gogacz, Istnieć i poznawać..., pp. 166-169 and 178-179. 
who am I? This question arises against the backdrop of the experience of one's cognition and the experience of oneself as the cognitive agent. These two kinds of experience are an effect of man possessing two types of consciousness: simple consciousness and self-consciousness. Simple consciousness is responsible for reacting to stimuli and mirroring objects. It is entirely different from the simple animal consciousness. It is richer in semantic information thanks to which man not only mirrors objects, but can also understand what they are, distinguish them from one another, approach them cognitively independently of practical needs and refer them to that which is general, developing concepts. ${ }^{20}$

The working of self-consciousness consists in referring all data to one centre - "I." It has two forms: non-reflective and reflective, that is introspective one called internal experience. Non-reflective selfconsciousness always accompanies simple consciousness, and its operation consists in man feeling himself to be the subject of his own conscious states, knowing that he is a human and knowing that he is different from all other objects in the surrounding world, as well as from other people. Non-reflective self-consciousness can turn into reflective self-consciousness, that is the subject's reflection on himself. ${ }^{21}$

What then is the subject? The fundamental structure of the subject consists in his being "reflective transcendence." "Reflective transcendence" is a formal expression used to define a basic "scaffold" of the human subjectivity. Here, "transcendence" means moving towards objective contents external to the subject, while "reflective" means mirroring them. The subject is not composed of the structure of reflective transcendence and some other component elements, but is a reflective transcendence. Its working consists in going "outside" itself, in mirroring objective contents and returning "to itself" to assimilate them. In the process it does not lose its identity or simplicity owing to the fact that it keeps its distance from all the absorbed contents. ${ }^{22}$

20 Cf. S. Judycki, Samoświadomość i unikalność..., p. 4.

21 Cf. ibidem, s. 4-5.

22 Cf. S. Judycki, Bóg i inne osoby..., pp. 116-117. 
As he defines the subject of consciousness more closely, Judycki notes that it does not identify with any of the consequences of temporal states: neither stream of consciousness states, nor physical brain states. The subject is irreducible to the contents of the stream of consciousness. It is nonspatial. The human "I" does not take up space; it has no length, no width, no depth. The subject is atemporal. It exists outside time, which is to mean that time and its changes do not "affect" its existence. This does not, however, mean the subject is timeless; it exists in time in the sense that it experiences time. But it can make it through time, not giving in to temporal occurrences and processes. My past "I's" - writes Judycki in the spirit of Roman Ingarden's phenomenology - are past only in appearance, because there is always one identical "I" that is present in different periods of time. Moreover, the subject is a unique unity and simplicity. The human "I" is not composed of parts that it could be divided into. ${ }^{23}$

The aspatial, atemporal, uniform and simple subject of consciousness, which does not identify with any of the consequences of temporal states, is a substantial subject. It is aware of its own existence through changes and of being the basis of the changes that occur in it. In the face of these changes it can act in a passive manner, but it can also initiate its own activity. It is capable of receiving data, understanding them, as well as of reacting to that which it mirrors. Judycki stresses the active role of the subject in conscious processes. The experience of subjectivity that takes place in intellectual immediacy is the experience of oneself as not only the "centre of activity," but simply a "causative power" originating acts of will, acts of thinking, acts of judgement and acts of evaluation. ${ }^{24}$

Judycki's concept of the uniqueness of the human person is a concept of the uniqueness of the subject of consciousness, that is the human soul. Man is merely individual. His soul is unique. Like Descartes, the author of Samoświadomość i pamięć assumes that man "is composed of"

23 Cf. ibidem, pp. 315-321.

${ }^{24}$ Cf. S. Judycki, Świadomość i pamięć. Uzasadnienie dualizmu antropologicznego, Lublin 2004, pp. 315, 346-347, 367, 382-383. 
a physical - biological - body and a spiritual soul, which interact with each other. He calls his theory an "interactionist-type anthropological dualism." He leaves open the issue of whether man is constituted by two substances or only one, i.e. whether it is only the immaterial soul, or perhaps the material body too, that has a substantial character. He claims that the soul is a radically heterogeneous substance relative to the body and that which is physical, but he does not decide whether the existence of the physical world is substantial. He recognises the possibility that souls are the only substances among beings, and physical objects are not substances at all or at least they are not substances in the sense that souls are. ${ }^{25}$

Recognising only the human soul as a unique person results in a question about the role of the body and the relationship between the soul and the body. A description of the "metaphysical birth" of the subject is the answer. Judycki claims that the subject of consciousness "begins" to exist the moment the first contents are accepted. Accepting the contents constitutes its "metaphysical birth." It consists in simple grasping of the contents (simplex apprehensio) which in a way triggers the "mechanism" of reflective transcendence, and is an act whereby "incarnation," that is embodiment of the subject, takes place. From this moment on one can speak about the existence of the subject and its experience of the body. The experience of one's own body comprises experience of visual body, that is an object that we observe in space next to other objects, experience of tangible body, which arises as a result of touching visual body and touching objects with it, experience of kinaesthetic body, which is a result of having special motor sensations, and experience of willing body, that is of a physical thing that we can freely move within certain limits. ${ }^{26}$

25 Cf. ibidem, p. 301.

26 "The willing body is in greatest «contact» with myself as a rational, will-endowed subject. The way it happens is that the experience «I can» concerns the kinesthetic, tactile and visual sphere, but also refers to the incorporeal sphere: not only can I reach for some object, but I can also stop thinking about one thing, and start thinking about another thing [...], etc." (S. Judycki, Bóg i inne osoby..., p. 132). 
An experiential synthesis of these bodies gives rise to a "phenomenal body" - an experience of a "living body." 27

The phenomenal body is a condition for the substantial subject's selfexpression, its "presence" for itself and other subjects. In the research paper Świadomość i pamięć Judycki points out that the body does not stand in the way of self-discovery or communication with other persons, but he adds that there are no empirical or conceptual reasons to believe that the human body is a suitable or optimal means of expression for the substantial subject. It is something purely contingent and unnecessary that the human soul appears in a physical body. Furthermore, there are no rational reasons to exclude the soul's capability to express itself not in one, but in many bodies (metempsychosis). As Judycki claims, using philosophical arguments, it is not possible to prove that a soul is assigned to one body only. However, it is possible on the theological plane. Therefore, the main difficulty that arises in Judycki's theory is the argument for the individuality of the human person. Since the body does not individuate a person, who himself is a simple quality, where is the reason for its individuality to be found?

According to Gogacz, to be an individuum means to be a real being formed out of unique principles. To be an individual human means to be a spiritual and corporeal entity formed out of an individual, rational soul and only its own, peculiar and specific body, and to be a spiritual and corporeal unity.

According to Judycki, to be an individuum means to be a living being, while to be unique means to be a person - a simple quality, a point of reference for conscious activities, a substantial subject, a causative power of cognition and action, a soul bound to a body and, by extension, experiencing the body and expressing itself in the body.

${ }^{27}$ Cf. ibidem, Świadomość i pamięć..., pp. 339-342. "[...] I wish to state that the experience of the «intimate union» between the subject and its body is a biradial experience: one radius follows towards the ever-present - as an actuality and ever-anticipated potentiality - synthesis of the kinesthetic, tactile and visual body, while the other one refers to the sphere of thinking and the sphere of decisions made by the will" (idem, Bóg inne osoby..., p. 132). 


\section{The reason for individuality}

\subsection{The reason for individuality from the perspective of Thomistic metaphysics}

In the Thomistic tradition - as Gogacz observes - the singularity of the human soul, after it has been separated from the body, used to be explained with the theory of commensuratio. The theory has it that after a man's death the human soul remains singular, because it is "directed" at the body, "oriented" towards the body from which it has become separated. A soul's being directed at a specific body is understood as a relation. This understanding contains an underlying assumption whereby the body is a separate thing, a substance at which a soul directs itself. Substantialising the body - claims Gogacz - is an error, because the body as a reason for the particularity of being is potency, a sum of privations measured out by a given form. For a form to measure out these privations, it needs to be singular. Therefore, the reason for its singularity cannot be matter, and that still holds in the face of the fact that from the viewpoint of time the effect that form has on matter and the effect that matter has on form are simultaneous. ${ }^{28}$

Gogacz can find a way to overcome these difficulties in modification of the theory of commensuratio whereby particularisation should be differentiated from singularisation. He claims that matter is not a reason for the singularity of the soul, but for its particularity. At the moment when the body is being actualised the soul is already singular, and owing to the fact that the body is actualised it becomes particular. The reason for the singularity of the soul must be something else than the body. It cannot be the act of existence, because the nature of the act does not involve limitation. Nor can it be assumed that God creating a particular soul right away is the reason, because that would imply the necessity to reject the pluralist thesis whereby the ontic structure of being contains all that constitutes it and on account of this "it is self-explanatory for what it is." ${ }^{29}$

28 Cf. M. Gogacz, Istnieć i poznawać..., pp. 185, 208.

29 Cf. ibidem. 
The reason for the individuality of the soul, which makes it capable of individual existence after being separated from the body, must be an element in the ontic structure, and it must be contained in the soul itself. Commensuratio construed traditionally as a soul's relational orientation towards the body excludes a singularising factor operating within the soul, because a relation as an accidental being is not an element in the ontic structure. What conditions then must the singularising factor meet? Above all, it must be potency, because its task is about limiting. The potency must be necessary and essential, because it must be unloseable for the soul. There is only one element in the soul's ontic structure that meets these conditions - the passive intellect. Commensuratio - as Gogacz believes - should be understood as the soul's internal singularisation by the passive ("commensurating") intellect, which adapts the soul to accept the particularity brought in by the body, so that the soul's main goal can be attained, that is cognition and free choice. ${ }^{30}$

The concept of the passive intellect as a soul-singularising factor justifies the need for the body in the human structure. Thanks to the body the soul can effect human cognition which has its origins in sense data. The modified theory of commensuratio also serves to defend the individual existence of the soul after a man's death, that is the immortality of a person. Like Judycki, Gogacz claims that the human soul is a human

30 Cf. ibidem, p. 193. And here arises the question of what role in a soul's individuation is played by the other spiritual powers, i.e. the active intellect and the will. Gogacz considers that only the passive intellect is the reason for individuation. "It appears that this role is played by the necessary potency only. And from this follows that it is not all the powers of the soul, as its potencies, that make this soul imperfect or individuate proportionately. Apart from the will this would also apply to the active intellect. But I highlighted only the passive intellect as the principle internally making the soul imperfect, as it is peculiarly primary in the soul. The free will acts already on the basis of the information provided by the passive intellect, which also requires the working of the active intellect, which in turn prepares intellectually cognitive contents. Thus, as they depend in action on the passive intellect, the will and the intellect are peculiarly secondary to it and subjectified in it. As regards nature, they too are - like the passive intellect - potency, which in action is, however, of a secondary character accidental in relation to it, and so it turns the soul to the body, so that cognition and a cognition-based choice of good are possible" (ibidem, p. 198). 
person..$^{31}$ Death annihilates a man, but not a person, because the principles of a person do not include a body. After a man's death, his soul lasts, devoid of the body, but oriented towards it and waiting to be reunited with it. ${ }^{32}$

\subsection{The reason for individuality from the perspective of phenomenological epistemology}

Judycki distinguishes between the experience of subjectivity and the experience of uniqueness. As regards the experience of subjectivity his position does not change. He claims that this experience is accessible in intellectual, that is non-sensory, immediacy. As regards the issue concerned with uniqueness his position evolves. In the 2004 treatise entitled Świadomość i pamięć. Uzasadnienie dualizmu antropologicznego

31 "In keeping with the substantialist perception of being, the ontic reason for a person cannot be outside the person. It is not embedded in man as man. Then it must be embedded in the soul. And for this reason in the strict sense it is the rational soul that is a person. In other words, the condition and carrier of the reason constituting the person is a spiritual being, that is a being whose existence is independent of the presence of matter [...]. Such an approach [...] [highlights - B. L.] that all the contents relevant to a given being are contributed to a specific substance by its substantial form. Because a soul is a person, a human is a person too. The thesis that the rational form contributes all the human species contents to the potential body underlies the conviction that the soul can be recognised as a person in the strict sense, and man can be recognised as a person in the broad sense" (M. Gogacz, Wokót problemu osoby..., pp. 172-173).

32 Also S. Swieżawski and A. B. Stępień find the thesis that the human soul, having been separated from the body, is still oriented towards it, to be the argument for the future resurrection of the body. Świeżawski writes: "The combination of the body and soul in man is so natural that death as a breakup of this hylemorphic compound is something tragic, a violation of nature, and that is why following man's death the soul, as it lives without the body, desires with all its essence to become combined with the body again, waiting for the body to be resurrected. And that is why the resurrection of the body, as presented to us in the Revelation, is in fact a return to the fullness of nature, even though as a fact it can only be effected miraculously, thanks to God's supernatural intervention (S. Swieżawski, Wstęp do „Kwestii 76”, [in:] Tomasz z Akwinu, Traktat o człowieku. Suma teologii 1,75-89, trans. and ed. S. Swieżawski, Kęty 1998, p. 80). Stępień expresses this thought as follows: "This new mode of being is something unnatural for the soul, if by nature it is supposed to be a substantial form of a specific body. That is why when separated from the body, the soul naturally strives to be reincarnated. Hence «the resurrection of bodies» is (in the philosophical scheme of things) at least probable" (A. B. Stępień, Wprowadzenie do metafizyki, Kraków 1964, p. 187). 
he claims that the experience of uniqueness is accessible to the subject in introspective reflection. He compares it to perception of a particular shade of colour for which we do not have a linguistic name, but we are able to distinguish it from other shades of the same colour. The subject experiences uniqueness as a peculiar "shade" of self-consciousness. The experience of one's uniqueness is very limited and vague, and in order to be able to specify it more clearly one would need to share in the experience of the uniqueness of other subjects. An experience like this, however, is not accessible to us. Other subjects are accessible to us only through the agency of their linguistic and non-linguistic behaviour. ${ }^{33}$

In the papers Samoświadomość i unikalność osób ludzkich of 2007 and Bóg i inne osoby. Próba z zakresu teologii filozoficznej of 2010 Judycki radicalises his position concerning a person's capacity for the internal experience of uniqueness. He no longer considers that it is vague, but finds it to be impossible at all. As he substantiates his thesis, he begins with an analysis of the term "person." In Antiquity it denoted a 'mask' used by theatre actors. Human consciousness, as it presents a mask of its own uniqueness, is an analogy of theatre. The uniqueness of one's own as well as of other persons is concealed under masks including, inter alia, the mask of the conviction that the subject one is is a pure "I," an empty pole to which all data and experiences relate to, the mask of character traits, the mask of matter one's body is composed of, etc. ${ }^{34}$

According to Judycki, the experience of one's own and other persons' uniqueness will only be accessible after death. This will be accomplished owing to "transfiguration," that is a qualitative "leap" taken by human consciousness. Judycki lists the consequences of this change in consciousness such as elimination of the opposition between

33 Cf. S. Judycki, Świadomość i pamięć..., p. 366.

34 Cf. ibidem, p. 368 and idem, Samoświadomość i unikalność..., pp. 10 and 12. "Any attempt at visualising the uniqueness of every specific person is that difficult, because the world [in - B. L.] which we live is a world of matter, and this in turn means that it is a world in which objects are subject to replication: there are many squirrels, many copies of Rafael's painting called Madonna Tempi, many people looking alike with similar character traits. It is matter that «covers» the uniqueness of persons in manifold manners" (S. Judycki, Samoświadomość i unikalność..., p. 12). 
phenomena and things-in-themselves, emergence of the capacity to directly experience and understand the way in which the general is realised in the particular (e.g. the way to realise the human species in a human individual), a change in the manner of relating to space and time (space will become

"internalised," and time will change its structure). All this - the philosopher conjectures - will be relative to the major change consisting in seeing oneself. Ours and other persons' masks will be torn off, and so we will have unmediated experience of ours and others' uniqueness; we will get to know the natures of particular persons and will see how ours and their consciousness follows from these natures. ${ }^{35}$

The experience of the uniqueness of persons "[...] would be equivalent to the enchantment experienced when watching a sunrise for the first time; the experience would be as dazzling as gazing right into the centre of nuclear explosion, and what is more, the intensity of the experience would never be subject to any schematisation, habituation, etc." ${ }^{36}$ To the question whether the experience would be like cognition of a sensory or rather intellectual character, Judycki answers that most probably it could be likened to the experience of pictorial beauty, which is both sensory and supersensory. ${ }^{37}$

In Judycki's opinion, the change to consciousness taking place at death is one of the elements of that which in Christianity is called "blessed vision." The basic element in this vision is a consciousness-based reference to God, viewing Him "face to face," as well as participating in the life of the Holy Trinity and human persons. The author of Świadomośc i pamięć surmises that access to this life will not be granted immediately, at one moment, but will be a process extending over time, with time having a completely different character than the one presently familiar

35 "Seeing oneself will be simultaneous with seeing the way in which one's consciousness is a derivative of one's individual essence" (S. Judycki, Bóg i inne osoby. Próba z zakresu teologii filozoficznej, Poznań 2010, p. 178).

${ }^{36}$ Idem, Samoświadomość i unikalność..., p. 8.

37 Cf. ibidem, p. 12. 


\section{to us. That will be unlimited and changed time of continual changes, ever new experiences and incessant, mutual understanding-suffused dialogue reflecting innermost human desires. ${ }^{38}$}

\section{But if in earthly life it is not possible to experience the uniqueness of one's own and other persons, then what grounds do we have to assume that}

persons are unique beings? Judycki answers this question on the theological plane. ${ }^{39} \mathrm{He}$ considers that the reason for the uniqueness of human persons is $\mathrm{God} . \mathrm{He}$ creates unique persons, because His intention “[...] can't have been to make happy the greatest possible number of entities who would differ from one another the way, say, fruit flies differ from one another. This would not be difficult for the Almighty God, but it would be unworthy of Him." ${ }^{40}$ If we presuppose that the purpose of human persons is eternal life with God - the author suggests - then we must assume that God did not want to create "pure subjects," or subjects devoid of uniqueness, and that He wanted unique beings to be destined for eternal life. Besides, man was created in the image and likeness of God, who despite being one, constitutes a Trinity of unique Persons. The happiness of the Divine Persons consists, inter alia, in engaging in constant communication. For similar communication to be possible among human persons,

38 Cf. S. Judycki, Bóg i inne osoby..., p. 220.

39 Judycki writes: "[...] apart from a purely analytical character, the whole of this argumentation is also of a confessional character, which means that it revolves around the contents acknowledged by religion, theology and Christian philosophy [...]" (S. Judycki, Samoświadomość i unikalność..., p. 11). This course of action is determined by the subject under discussion and its purpose. In the research paper Bóg $i$ inne osoby, which is an elaboration of the ideas contained in Samoświadomość $i$ unikalność..., Judycki employs the same method. He justifies the employment of it as follows: „ "Bóg $i$ inne osoby» is an attempt at philosophical discussion and consolidation of some basic convictions concerned with Christian religion and theology. The philosophical character of this book lies in, inter alia, the fact that I try to formulate the reasons for the existence of God, the necessity for Incarnation [...], and these reasons do not refer to the Christian Revelation as the so-called context of substantiation, but solely as the context of discovery. I also address philosophical issues concerned with the nature of consciousness and the nature of the soul, the living human body, the essence of communication between persons, eternal life, omnipotence, the triple nature of God, and the history of human persons. [...] I am convinced that there can be no philosophy which, if thoroughly pursued, could not produce the effects of theoretical relevance for the fundamental issues concerned with the Christian outlook on life" (S. Judycki, Bóg i inne osoby..., pp. 11-12).

${ }^{40}$ S. Judycki, Samoświadomość i unikalność..., p. 2. 
and for it to be exciting enough to provide eternal life with meaningful content, it is necessary that human persons are unique beings. ${ }^{41}$

As we mentioned before, the reason for the individuality of a human person (a soul) in Gogacz's pluralistic metaphysics is the passive intellect, exposed with the method of identification of the principles of being. It serves to explain the presence of a body in man's ontic structure, as well as the "assignment" of a soul to one body, and its individual existence after man's death. In Judycki's phenomenological epistemology a human person (a soul) is a simple quality. It experiences itself as a subject, but it does not experience itself as as a unique subject. The reason for uniqueness is not identifiable within the field of philosophy, and requires a recourse to theology. The reason is God, who created man in his image and likeness.

\section{The concept of a human person}

In the history of philosophy there are two main trends in perception of the human person: a substantialist and a relationalist one. The substantialist trend has its origins in Aristotle's philosophy and is based on his theory of substance, that is an autonomous being whose existence does not require any other being external to it. The relationalist trend is a continuation of Plato's thought. Its authors construct a concept of person by referring to his relationships with other beings: human persons (e.g. Martin Buber), God (e.g. Karl Rahner), society (e.g. Karl Marx), nature (e.g. Pierre Teilhard de Chardin), culture (e.g. Claude LéviStrauss) or himself, his own existence (e.g. Karl Jaspers). The point of the substantialist concepts is to recognise the human person as an ontically complete being containing within its ontic structure all its constitutive principles. The point of the relationalist concepts is to recognise the person as a part of a bigger whole, e.g. society, culture, nature, and by 
extension - to acknowledge that some of his principles are to be found beyond its ontic sphere. ${ }^{42}$

\subsection{The Thomistic concept of the human person}

Gogacz's concept of person is a substantialist approach constructed upon the foundation of the approaches developed by Aristotle, Boethius and Saint Thomas Aquinas. The author of Elementarz metafizyki defines the person as a "self-contained individual being," an "autonomous individual being" and "subsistence." However, unlike Saint Thomas Aquinas, he claims that man is a person in the broad sense, while in the narrow sense it is the human soul, and not man, that is a person. ${ }^{43}$ He refers to the person as "[...] an individual being whose existence through its manifestations releases a personal relation of love, faith and hope, while triggering rationality in the essence of this being. In other words, a person is an individual and rational being capable of love and trust." ${ }^{44}$ Next to the act of existence, the above-cited definition mentions rationality among the principles of the person. As was stated before, the reason for the person is the passive intellect present in the structure of the soul. Thus, the appellation of rational being is due to man even if he does not or cannot create concepts, judgements or reasonings. The subject of these actions is the active intellect, which constitutes a person's immaterial (spiritual) accident. However, it is not a cause of a possible

${ }^{42}$ Cf. M. Gogacz, Wokót problemu osoby..., p. 17. Gogacz explains the basis for the division of concepts of the human person into substantialist and relationalist ones in the following way: "The Platonic manner in which the human person is characterised comes down to the claim that that which a given human is is to be found outside him. Thus, the human person is constituted by his relationship with beings found outside the ontic sphere of man. Such a manner of characterising the human person can be termed a 'relationalist approach.' The Aristotelian manner of describing the human person can be encapsulated in the claim whereby that which a given man is constitutes him internally. This internal ontic content of man's is an autonomous, self-sufficient, non-absolute being called 'substance.' The Aristotelian manner of describing the human person can be termed a 'substantialist approach' (ibidem).

${ }^{43}$ Cf. note 31 .

${ }^{44}$ M. Gogacz, Wprowadzenie do etyki chronienia osób, Warszawa 1998, p. 9. 
lack of intellectual competence. The cause includes bodily dysfunctions preventing proper working of sensory powers operating from their own organs inside the body. Inappropriate working of the sensory powers prevents the operation of the active intellect, because - according to the Aristotelian principle - nothing is in the intellect that was not first in the senses. Thus, in the scheme of Gogacz's concept of person, no man can be denied the appellation of rational being, and therefore the appellation of person.

Gogacz spares relatively little attention to the issue of cognition of a person's individuality. Pursuing the ramifications of his concept of person and of personal relationships, one can assume that he finds observation and analysis of external reality to be the path leading to cognition of a person's individuality. As a continuator of Saint Thomas Aquinas' philosophy, he believes that we are not granted direct cognitive access to our own souls, but we know them indirectly through their activities. We get to know other persons by establishing personal relationships with them. Establishing relationships is a natural consequence of being a person, a result of a person's spontaneous reaction to another person. Personal relationships are characterised by bidirectionality and being founded on the transcendental manifestations of existence. ${ }^{45}$ The reality of persons underlies the relationship of love that takes the form of amor (romantic love), caritas (parental love), agape (love between God and man) and amicitia (friendship); the truth underlies the relationship of faith, which in its active aspect takes the form of veracity, while in its passive aspect - of trust; good underlies the relationship of hope, the active aspect of which is doing good, the passive aspect being anticipation

45 “The personal effect of transcendental properties on other persons' transcendentals takes place independently of cognition and decisions. Cognition and decisions only cause one to make use of these relationships, protecting or destroying them. Protecting and destroying here means deepening personal relationships, their growing intensity, and not annihilation. When beings exist and their existence is manifested, relationships of an existential character are established between them, while between persons relationships of a personal character are established. Personal relationships take precedence over all other relationships, because all the content of being is preceded by its specific act of existence" (M. Gogacz, Elementarz metafizyki, Warszawa 1998, pp. 50-51). 
of good. Personal relationships are established between human persons, as well as between human persons and God.

\subsection{The phenomenological concept of the human person}

As Judycki notes, the philosophical tradition typically defines the person as a conscious and self-conscious, rational and free being capable of responding to values and of creating culture. Such a definition is essentially correct, though incomplete, because its characterisation of the person is only formal. It points to what is common to all persons, but does not say anything about their uniqueness. In Judycki's approach, to be a human person means to be a unique entity, radically different from all other human entities. He uses the following terms to refer to the person: a "subject of consciousness," "reflective transcendence," a "substantial subject," a "soul" and a "unique quality." The majority of these are definitions based on a cognitive perspective. In Judycki's approach a human person is a unique subject capable of consciousness and cognition. In the light of the concept of "reflective transcendence" one might even say that it is a subject constituted by cognition.

Judycki's theory of the person is a synthesis of the relationalist and substantialist approaches. It is grounded in Descartes's philosophy of the subject, but on account of the substance theory it refers to object philosophy. The theory of substance employed by Judycki is not a classical theory. The author of Świadomość i pamięć modifies the Aristotelian definition of substance, introducing relationalist elements derived from the philosophy of Plato and Saint Augustine. Like the latter one, he assumes that the relationships that bind a person to other persons are intrinsic to his essence. "The person - he believes - is something stable, persevering through the changes to his states and being the subject of these, and in this sense the person is a substance, but at the same time it is peculiar to his essence, and hence to his substance, to engage in relationships. A lonely person could not be a person, the theological proof of this being the Holy Trinity, where the relationships between the 
persons are not exclusively accidental, and therefore unnecessary, but are of a substantial character." ${ }^{36}$

The synthesis of the relationalist and substantialist perception of the person

in Judycki's philosophy constitutes an implication of the quest for the answer to the question about the uniqueness of the human person in the opposing philosophical concepts - the relationalist approaches of Plato, Saint Augustine and Descartes as well as the substantialist approaches of Aristotle and Saint Thomas Aquinas. A verbal manifestation of this synthesis is the use of the term "substantial subject" which is a combination of the term "subject," characteristic of relationalist philosophy, and the term "substance," typical of object philosophy.

The distinctive feature of Judycki's concept of the human person is its focus on the issue of uniqueness. Not only does the author of Świadomośc $i$ pamięc ask whether the experience of uniqueness is possible and how it might present itself in consciousness, but he also takes up the issue of its implications. He enumerates a few of these. The first one is the absence of boundaries in qualitative differentiation of persons. Human persons differ radically, even though from our viewpoint they appear to be alike. Taking into consideration all persons who have lived, live and will live in the future, there is an infinite number of unique persons. The second implication of the uniqueness of persons is the uniqueness of interpersonal connections. Since every person is a radically unique being, all the relationships he builds are radically unique. The third implication is the infinity of persons' cognitive activity. Even though a self-conscious subject, as he mirrors a variety of objects, in a way "becomes" them, cognition never "fills" him to the degree that his activity should come to an end. Every time the subject receives data, it goes beyond them, opening up to new data. Judycki calls these three implications of the uniqueness of human persons three "infinities": the infinity of unique 
human persons, the infinity of possible relationships between them, and the infinity of their cognitive activity. ${ }^{47}$

Even though Gogacz's and Judycki's concepts of the person have different foundations, in several issues they are convergent. Both the philosophers assume that: 1 . The person is an individual being; 2. A human soul is the person; 3 . A person's individuality is closely related to his intellectual capacity (Gogacz relates it to the passive intellect, while Judycki relates it to self-consciousness and manner of cognition); 4. The human soul is radically different from the body and is immortal; 5. Establishing and maintaining relationships with other human persons and God is an intrinsic feature of the person. With regard to the latter issue, the presented concepts of the person seem the most convergent. In Gogacz's opinion it is the environment of persons, and not nature or the world of culture, that is "man's true world," the world in which he "makes himself at home," feels happy and where staying is the meaning of his life. Judycki writes: "It is not that people are predestined to exist by the

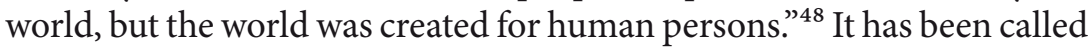
world only because it is populated by self-conscious beings who build interpersonal relationships. The purpose of persons is eternal life with other persons. Underlying this life is "existential" communication which is not only about conveying unique contents, but also about participation in other persons' lives. ${ }^{49}$

\section{Conclusion}

Thomism and phenomenology investigate different types of experience, employing different conceptual apparatuses and different research methods. Their analyses give rise to different kinds of problems and make it necessary to pose different questions. The rationale behind the present discussion was to show that these two different perspectives

47 Cf. ibidem, pp. 12-13 and S. Judycki, Bóg i inne osoby..., pp. 16-17 and 214.

48 S. Judycki, Bóg i inne osoby..., p. 17.

49 Cf. ibidem, pp. 154-155. 
lead to two complementary images of the individual human person: an objective and a subjective one. These images cannot be simply "added" to each other, but on the other hand they are evidently complementary, which Karol Wojtyła emphasised and to which he referred in his philosophical anthropology. ${ }^{50}$ The complementary natures of Thomism and phenomenology are understood here as providing an answer to the questions that cannot be answered by either of the two philosophical trends alone. This may be illustrated exactly by Gogacz's and Judycki's concepts. From the perspective of Gogacz's Thomism the questions concerned with a person's manner of experiencing himself as a being capable of cognition, action, equipped with a body, as well as with a possible way of experiencing his own individuality prove insoluble. From the perspective of Judycki's phenomenology the questions concerned with the reason for a human person's individuality and a cause for his "incarnation" prove insoluble. The benefits of considering the individuality of the human person from both the Thomistic and phenomenological perspective appear to be worthwhile. From the viewpoint of Gogacz's Thomism the major ones include broadening the horizon of discussion to include the sphere of the subject's experience, while from the viewpoint of Judycki's phenomenology - staying within the bounds of philosophy without the necessity of referring to theological deliberation.

A juxtaposition of Gogacz's and Judycki's concepts of the individuality of human persons shows that the knowability of uniqueness is a philosophical problem. Is it really insolvable? As yet too little has been said in the field of metaphysics about the uniqueness of human persons

50 The way in which Wojtyła combined the Thomistic reflection with phenomenological reflection in his discussion of man can be characterised thus: "According to Wojtyła it is not so much about the phenomenological justification for the way man is a person, but about using phenomenology to see how man is a person, how the metaphysical structures characterising his personal existence become reflected in his conscious existence. Therefore, the metaphysical Thomistic anthropology is here in a way present all the time, as a grand fundamental hypothesis which comes to be verified by a phenomenological analysis, and which - on the other hand - constantly guides the analysis, allowing it to become more profound" (R. Buttiglione, Kilka uwag o sposobie czytania "Osoby i czynu”, trans. T. Styczeń, [in:] K. Wojtyła, “Osoba i czyn” oraz inne studia antropologiczne, Lublin 2000, p. 15). 
for anyone to be able to authoritatively settle the issue concerned with the possibility of experiencing it. Hence, it is premature to state that we will never be able to find out what it is about. The discussion of the uniqueness of human persons is worth undertaking, and in a variety of philosophical trends for that matter. Apart from pursuing Thomistic and phenomenological analyses, of particular value might be discussion in the field of philosophy of dialogue, philosophy of language, philosophy of mind, which is indicated by the role of interpersonal relationships, and by extension communication, highlighted in Gogacz's and Judycki's concepts. There is a possibility that the thing that is researchwise difficult in one philosophical trend might be less intractable in another one on account of resorting to a different conceptual apparatus and different research methods. It is worth posing the question about the uniqueness of the human person, even if it appears to be "[...] one of the most difficult, if not the most difficult one of philosophical questions." ${ }^{51}$ Let us add that from the viewpoint of philosophical anthropology, it is one of the most interesting questions.

\section{Abstract}

The aim of the article is presentation of two concepts of human individuality which have arisen in modern Polish philosophy of Mieczysław Gogacz and Stanisław Judycki. It is an attempt to look at the problem from two different philosophical perspectives: Thomistic metaphysics and phenomenological epistemology. Metaphysical approach is searching for an answer to the question about human individuality in their ontic structure, whereas phenomenological approach focuses on the analysis of a direct experience. As reason of individuality, Gogacz indicates potential intellect (passive) subjected in a substantial form (soul). Judycki maintains that this reason is the concept of God, according to whom He creates a soul of every human being as radically different from all other human souls, unique. Presented theories develop from a different way of understanding a human being. Gogacz's theory has a substantial character, refers to the concept of a human of Aristotle, Boethius and St. Thomas Aquinas. Judycki's concept is

51 S. Judycki, Bóg i inne osoby..., p. 177. 
a relational approach, modified by elements of substantialist philosophy. He refers to relational approach of Plato, Saint Augustine and Descartes as well as substantialist theories of Aristotle and St. Thomas Aquinas. Thomistic and phenomenological approaches to individuality introduce fundamentally different and essential substance to philosophy concerning human beings.

\section{Keywords}

Pluralism, dualism, human, individuality, Thomism, Phenomenology

\section{Bibliography}

Gogacz M., Elementarz metafizyki, Warszawa 1998.

Gogacz M., Istnieć i poznawać, Warszawa 1976.

Gogacz M., Wokót problemu osoby, Warszawa 1974.

Gogacz M., Wprowadzenie do etyki chronienia osób, Warszawa 1998.

Judycki S., Bóg i inne osoby. Próba z zakresu teologii filozoficznej, Poznań 2010.

Judycki S., Świadomość i pamięć. Uzasadnienie dualizmu antropologicznego, Lublin 2004. Kijewska A., Filozof i jego muzy. Antropologia Boecjusza - jej źródła i recepcja, Kęty 2011. Krąpiec M. A., Zagadnienie jednostkowienia bytów materialnych, „Roczniki Filozoficzne” 1958, vol. 6 bull. 1, pp. 97-148.

Stępień A. B., Wprowadzenie do metafizyki, Kraków 1964.

Tomasz z Akwinu, Traktat o człowieku. Suma teologii 1,75-89, trans. and ed. S. Swieżawski, Kęty 1998.

Wojtyła K., „Osoba i czyn” oraz inne studia antropologiczne, Lublin 2000.

Ziemiński I., Życie wieczne. Przyczynek do eschatologii filozoficznej, Kraków-Poznań 2013. Judycki S., Samoświadomość i unikalność osób ludzkich, http://www.kul.pl/materialy-do-pobrania,art_19301.html (02.04.2014).

Thomas Aquinas, Contra Gentiles. On the Truth of the Catholic Faith, Book Two: Creation, translated by James F. Anderson, New York, 1955-57, http://dhspriory.org/thomas/ ContraGentiles2.htm\#81 (02.04.2014). 